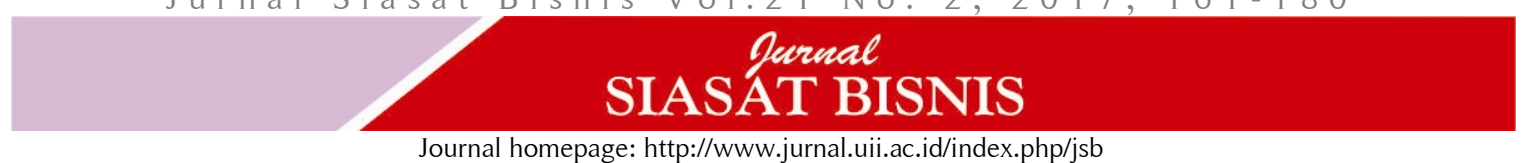

\title{
Nilai orientasi alami manusia dan pengetahuan organik sebagai determinan perilaku beli pangan organik
}

\author{
Tony Wijaya \\ Fakultas Ekonomi, Universitas Negeri Yogyakarta, Yogyakarta, Indonesia \\ E-mail: drtonyw12@gmail; tony@uny.ac.id
}

\begin{abstract}
This study aimed to examine the model of consumer's buying behavior towards organic food. This model presents the effects of human nature's value orientation, organic knowledge, organic food buying attitude, subjective norms, behavioral control and buying intentions toward organic food buying behavior. This research was conducted by survey method. Data collection was conducted by purposive sampling technique. Total of 516 respondents from Yogyakarta, Surabaya, and Jakarta were ready to participate in this study. A Structural equation modeling (SEM) is used to analyze the data.

The tested model in this research is fit to the empirical data. Man-nature orientation and organic knowledge significantly give positive effect for attitude toward buying organic food. Attitude toward buying organic food, subjective norm, and behavioral control significantly give positive effect for buying intention toward organic food. Behavioral control gives positive effect but not significant for buying behavior toward organic food. Buying intention toward organic food significantly gives positive effect for buying behavior toward organic food.
\end{abstract}

Keywords: man nature orientation, organic knowledge, buying behavior, organic foodKeywords: man nature orientation, organic knowledge, buying behavior, organic food.

\begin{abstract}
Abstrak
Penelitian ini bertujuan menguji model perilaku beli pangan organik. Model ini mempresentasikan pengaruh dari orientasi nilai alami manusia, pengetahuan organik, sikap membeli pangan organik, norma subjektif, kontrol perilaku and niat beli terhadap perilaku beli pangan organik. Penelitian ini menggunakan metode survei. Pengumpulan data dilakukan dengan teknik purposive sampling. Sejumlah 516 responden dari Yogyakarta, Surabaya dan Jakarta berpartisipasi dalam penelitian ini. Structural equation modeling (SEM) digunakan untuk analisis data.

Pengujian model sesuai dengan data empiris. Orientasi alami manusia dan pengetahuan organik berpengaruh secara positif dan signifikan terhadap sikap membeli makan organik. Sikap membeli pangan organik, norma subjektif dan kontrol perilaku berpengaruh secara positif dan signifikan terhadap niat beli makan organik. Kontrol perilaku memberikan kontribusi positif namun tidak signifikan terhadap perilaku beli pangan organik. Niat beli pangan organik berpengaruh positif dan signifikan terhadap perilaku beli pangan organik.
\end{abstract}

Kata kunci: orientasi alami manusia, pengetahuan organik, perilaku beli, pangan organic.

$$
\text { JEL: D12, D83, P46 }
$$

DOI: 10.20885/jsb.vol21.iss2.art5

\section{Introduction}

Masalah keamanan pangan (food safety), kandungan nutrisi (nutritional attributes) dan ramah lingkungan (eco-labelling) menjadi isu yang terus berkembang dalam industri pangan. Isu keamanan pangan telah meningkatkan kepedulian masyarakat pada lingkungan yang menuntut setiap orang untuk memiliki pola hidup sehat serta cenderung alami (Chan, 2001). Peningkatan kebutuhan kualitas di bidang pangan dan kesehatan terbentuk karena keyakinan bahwa pangan yang sehat dan alami dapat menurunkan prevelensi berbagai penyakit (Nord, 2009). Fenomena ini menimbulkan permintaan dan konsumsi produk yang terkait dengan pemeliharaan kesehatan (Syahlani, 2006; Worsley \& Scott, 1999) terutama pangan organik yang bebas dari bahan-bahan kimia berbahaya. 
Hasil survey penelitian YLKI (2012) menunjukan tingkat konsumsi pangan organik di beberapa wilayah di Indonesia tergolong rendah. Alasan yang menjadi faktor konsumen tidak membeli pangan organik antaralain harga yang tinggi, masalah distribusi dan lokasi penjualan yang sulit diakses untuk mendapatkan manakan organik. Sebagian konsumen tidak mengetahui tentang pangan organik. Faktor akses dan lokasi distribusi masih menjadi persoalan utama konsumen untuk memperoleh produk pangan organik.

Beberapa studi terkait konsumen ramah lingkungan berupaya mengungkapkan faktor-faktor yang menjadi determinan perilaku pembelian produk pangan yang ramah lingkungan. Tinjauan hasil penelitian perilaku konsumen pangan organik mengelompokkan faktor determinan bagi perilaku pembelian pangan organik yaitu nilai konsumen (Chan, 2001; Chan \& Lau, 2000; Fraj \& Martinez, 2006), pengetahuan (Chan, 1999; Chan \& Lau, 2000; Magistris \& Gracia, 2008), sikap konsumen (Aertsens et al., 2009; Gracia \& Magistris, 2007; Lodorfos \& Dennis, 2008; Wijaya \& Suprapto, 2012a), norma subjektif (Wijaya, 2012a ;Aertsens et al., 2009; Lodorfos \& Dennis, 2008; Sampson, 2009), kontrol perilaku (Aertsens et al., 2009; Lodorfos \& Dennis, 2008; Tarkiainen \& Sundqvist, 2005; Wijaya, 2012a). Variabel-variabel tersebut dikategorikan sebagai nilai, pengetahuan, sikap dan perilaku (Chan \& Lau, 2000; Chan, 2001; Follows \& Jobber, 2000) yang mengacu pada model dasar teori perilaku terencana.

Konsep tentang pangan memiliki muatan nilai bagi konsumen. Nilai juga dipertimbangkan untuk mengidentifikasi segmentasi konsumen khususnya pada produk-produk ramah lingkungan (Engel et al, 2005; Fraj \& Martinez, 2006). Nilai menjadi acuan dasar bagi konsumen dalam mengambil keputusan terkait konsumsi produk ramah lingkungan. Nilai merupakan bagian dari bagian keyakinan konsumen untuk bersikap dan berperilaku, sedangkan pengetahuan digunakan dalam melakukan evaluasi atau pertimbangan dalam pengambilan keputusan. Beberapa studi membuktikan adanya pengaruh nilai terhadap sikap konsumen hijau seperti Chan (2001) dan Chan \& Lau (2000).

Selain aspek nilai, faktor pengetahuan konsumen juga perlu dipertimbangkan dalam penelitian perilaku konsumen karena berkaitan dengan pertimbangan pembelian. Lodorfos \& Dennis (2008) menyarankan pentingnya informasi sebagai bagian dari pengambilan keputusan konsumen hijau. Sikap yang menjadi komponen dasar dalam teori perilaku terencana ditentukan oleh tingkat keyakinan individu dan dapat berubah sesuai dengan tingkat pengetahuan (Aertsens et al, 2009). Aspek pengetahuan konsumen menjadi salah satu pertimbangan konsumen dalam mengevaluasi produk. Pengetahuan produk menunjukkan seberapa besar informasi produk yang telah diserap oleh konsumen (Engel et al, 2005). Konsumen yang memiliki pengetahuan tentang produk akan mengabaikan harga premium dari produk ramah lingkungan yang akan dikonsumsi. Gracia \& De Magistris (2007) mengungkapkan bahwa pengetahuan konsumen menjadi pertimbangan konsumen dalam membedakan atribut-atribut produk organik dengan produk konvensional lainnya, serta evaluasi konsumen pada produk organik. Beberapa penelitian mengindikasikan adanya peran parsial pengetahuan organik terhadap perilaku konsumsi produk organik (Poelman et al., 2008; Schlegelmilch et al., 1996; Junaedi, 2006; Gracia \& Magistris, 2007; Magistris \& Gracia, 2008; Amyx et al, 1994; Vining \& Ebreo, 1990; Chan, 1999; Yiridoe et al., 2005).

Penelitian ini memperluas penelitian Sampson (2009), Lodorfos \& Dennis (2008), Kalafatis et al., (1999), Chiou (1998) dan Tarkiainen \& Sundqvist (2005). Kalafatis et al., (1999) yang menggunakan model theory planned of behaviour dalam memprediksi niat beli pada Belanda dan Yunani. Penelitian sebelumnya tidak melibatkan aspek nilai maupun pengetahuan konsumen secara komprehensif sebagai faktor latarbelakang dalam perluasan model modified theory planned behaviour. Hal yang mendasari pentingnya aspek nilai dan pengetahuan dalam perilaku pembelian didasarkan pada pendapat bahwa pengetahuan, sikap, dan nilai akan membantu dalam menciptakan kepedulian, perhatian dan perilaku konsumen yang ramah terhadap lingkungan (Umberson, 2008; Bui, 2005; Mansaray \& Abijoye, 1998; Chen \& Chai, 2010). 
Penelitian secara khusus bertujuan menguji pengaruh simultan dan parsial dari variabel prediktor yang diteliti terhadap perilaku beli pangan organik sesuai dengan rancangan model yaitu pengaruh variabel nilai orientasi alami manusia, pengetahuan organik, sikap membeli pangan organik, norma subjektif, kontrol perilaku dan niat beli terhadap perilaku beli pangan organik.

\section{Kajian Pustaka}

Berdasarkan kerangka teori yang dibangun dari teori perilaku terencana modifikasi, model konseptual berupa kerangka umum dalam penelitian ini mengambarkan bahwa faktor latar belakang yang terdiri dari faktor personal, sosial dan informasi menentukan sikap berperilaku. Selanjutnya sikap berperilaku, norma subjektif dan kontrol perilaku beserta kontrol perilaku aktual akan mempengaruhi intensi berperilaku dan pada akhirnya akan mempengaruhi perilaku aktual. Secara grafis, model konseptual digambarkan sebagai berikut:

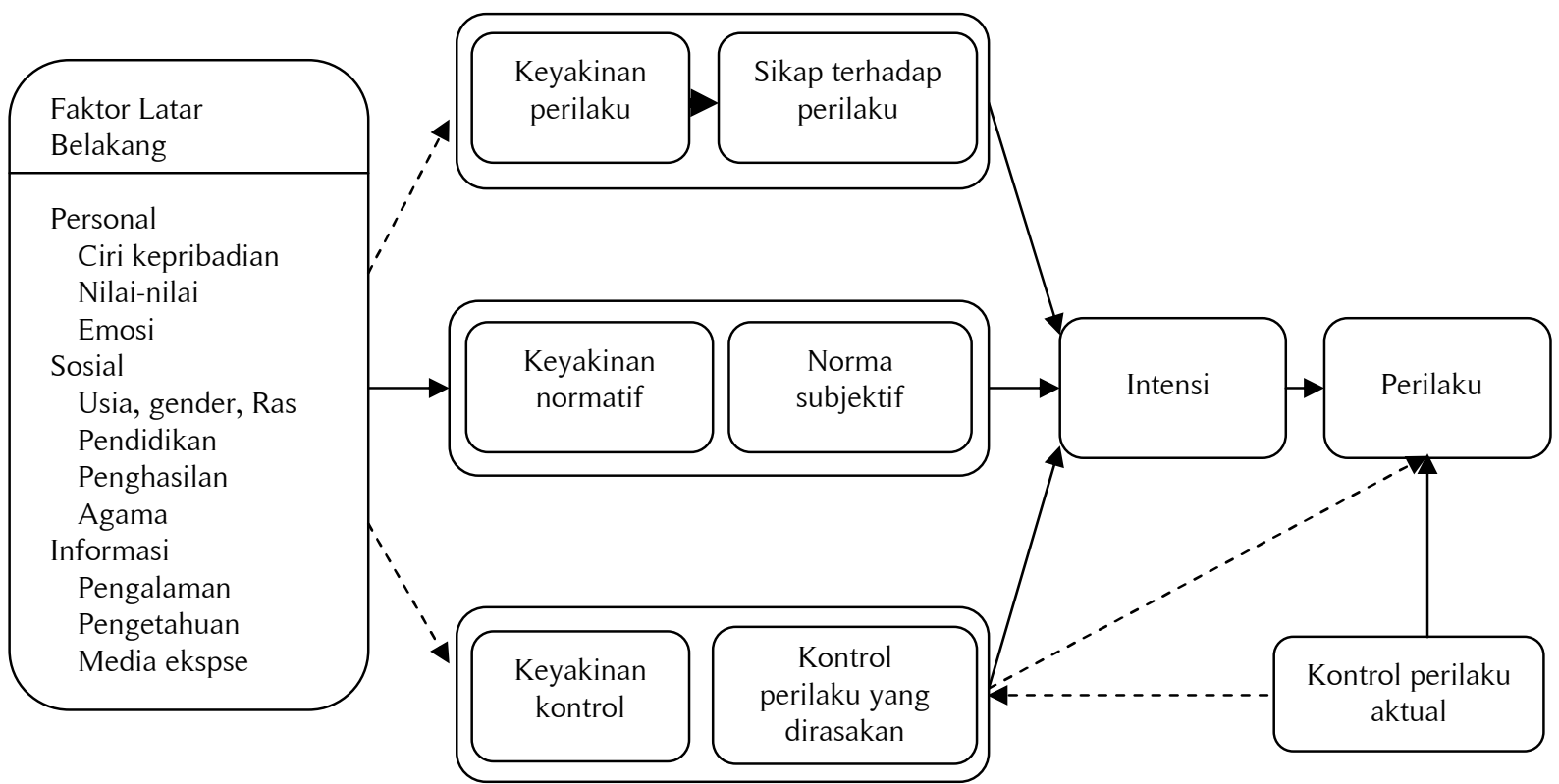

Gambar 1. Modified Theory Planned of Behaviour

Faktor latar belakang merupakan faktor dasar yang menjadi anteseden bagi sikap berperilaku meliputi faktor personal, sosial dan informasi. Faktor personal merupakan karakteristik atau ciri melekat pada individu meliputi ciri kepribadian, nilai-nilai dan emosi dari individu. Ciri kepribadian merupakan satu pola ciri atau sifat yang relatif menetap dan karakter unik yang menentukan perilaku individu secara konsisten dan khas (Santrock, 2005) seperti introversi, ekstraversi, instabililitas, dan stabilitas. Nilai memberi arah pada sikap, keyakinan dan tingkah laku seseorang, serta memberi pedoman untuk memilih tingkah laku yang diinginkan pada setiap individu. Lima ketegori orientasi nilai konsumen yaitu man-himself (human) orientation, man-nature orientation, relational orientation, past-time (time) orientation, dan activity orientation. Orientasi nilai tersebut secara khusus berkaitan dengan perilaku konsumen (Churchill, 1979; Engel et al, 2005). Nilai yang berhubungan dengan perilaku ramah lingkungan adalah nilai orientasi alami manusia (man-nature orientation) (Chan, 2001).

Faktor sosial merupakan karakteristik yang memiliki asosiasi dengan kelompok sosial individu meliputi usia, gender, ras, pendidikan, penghasilan, dan agama. Faktor cenderung merupakan aspek demografi individu yang diakui oleh lingkungan sosial. Usia, gender, ras, pendidikan, penghasilan dan agama merupakan pengelompokkan individu yang diterima oleh lingkungan sosial. Faktor informasi merupakan aspek kognisi atau kandungan informasi yang melekat pada individu meliputi pengalaman, pengetahuan dan media ekspose. Pengalaman berkaitan dengan keterlibatan 
subjek yang berkaitan dengan objek psikologis. Pengetahuan adalah semua informasi yang dimiliki konsumen mengenai berbagai macam produk, serta pengetahuan lainnya yang terkait dan informasi yang berhubungan dengan perannya sebagai konsumen. Pengetahuan konsumen terbagi dalam tiga macam yaitu pengetahuan produk, pengetahuan pembelian dan pengetahuan pemakaian. Menurut Engel et al (2005) pengetahuan produk adalah kumpulan berbagai macam informasi mengenai produk. Pengetahuan meliputi terminologi, kategori produk, dan atribut produk. Jenis pengetahuan produk dikategorikan sebagai pengetahuan tentang karakteristik atau atribut produk, pengetahuan tentang manfaat produk dan pengetahuan tentang kepuasan yang diberikan produk kepada konsumen.

\section{Nilai Orientasi Alami Manusia}

Pangan organik sebagai produk ramah lingkungan merupakan bagian dari sistem keyakinan individu (Dembkowski \& Lloyd, 1994). Keyakinan manfaat pangan dan nutrisi merupakan bagian budaya bagi beberapa bangsa di Asia seperti Cina, Jepang, Korea dan beberapa negara lainnya (Verschuren, 2002; Westrate, 2002). Nilai dianggap penting oleh sekelompok masyarakat karena berperan mengarahkan perilaku. Dalam berperilaku individu diarahkan oleh nilai yang sesuai dengan budaya dari individu.

Konsumen produk ramah lingkungan memuat nilai-nilai yang berorientasi pada hubungan manusia dengan alam sehingga lebih mempertimbangkan dampak dari konsumsi terhadap lingkungan. Nilai konsumen secara umum dapat dibedakan dalam beberapa tipe yaitu man-nature orientation, man-himself orientation, relational orientation, past-time orientation, dan activity orientation. Tipe nilai menurut Kluckhohn dan Strodtbeck (1961) yang mampu memprediksi perilaku pembelian produk ramah lingkungan adalah orientasi alami manusia yang berfokus pada hubungan manusia dengan alam dan kehidupan yang harmonis dengan lingkungannya.

Penduduk Asia memandang diri mereka sebagai bagian dari alam dan hidup harmonis dengan alam atau berorientasi pada alam (de Mooij, 2004) yang disebut Chan (2001) sebagai orientasi alami manusia (Man Nature Orientation). Beberapa studi menunjukkan nilai konsumen memiliki pengaruh yang positif terhadap sikap konsumen pada produk organik (Dreezens et al., 2005; Krystallis et al., 2008; Grunert \& Juhl, 1995; Durham \& Andrade, 2005; Kuhar \& Juvancic, 2005; Midmore et al., 2005; Padel \& Foster, 2005; Verhoef, 2005; Gracia \& de Magistris, 2007; Stobbelaar et al., 2007). Orientasi alami manusia mengarah pada hubungan manusia dengan alam sehingga konsumen berupaya mencari atau memperoleh informasi-informasi yang berkaitan dengan masalah lingkungan. Dengan demikian konsumen yang memiliki orientasi nilai alami manusia akan memiliki sikap yang mendukung konsumsi produk organik (Wijaya \& Hidayat, 2011; Wijaya \& Suprapto, 2012b). Studi meta-analisis menunjukkan hubungan nilai dengan sikap konsumen organik yaitu sebesar 0,324 (Chan, 2001). Hipotesis yang diajukan sebagai berikut:

H1: Nilai orientasi alami manusia berpengaruh positif terhadap sikap membeli pangan organik

\section{Pengetahuan Organik}

Pengetahuan adalah salah satu karakteristik yang mempengaruhi proses pengambilan keputusan. Pengetahuan merupakan faktor relevan yang mempengaruhi konsumen dalam mengumpulkan dan mengorganisasikan informasi yang diterima (Alba \& Hutchinson, 1987), menggunakan informasi yang diterima untuk pembuatan keputusan dan menggunakan informasi sebagai evaluasi produk yang akan dikonsumsi (Martin \& Simintras, 1995). Pengetahuan konsumen adalah semua informasi yang dimiliki konsumen mengenai berbagai macam produk, serta pengetahuan lainnya yang terkait dan informasi yang berhubungan dengan perannya sebagai konsumen (Engel et al, 2005).

Peattie (1998) menjelaskan secara analogi konsep green marketing, bahwa konsumen yang memiliki pengetahuan yang baik memiliki kecenderungan untuk melakukan pembelian produk yang ramah lingkungan. Konsumen yang memiliki kesadaran akan pentingnya dampak pembelian lebih 
memilih untuk membeli pangan organik (Follows \& Jobber, 2000; Vlosky et al, 1999; Bui, 2005; Laroche et al, 2001). Pengetahuan tentang pangan organik berfungsi sebagai pertimbangan konsumen untuk menentukan sikap pada pangan organik (Amyx et al., 1994; Chan, 1999; Yiridoe et al., 2005; Poelman et al., 2008; Schlegelmilch et al., 1996; Junaedi, 2007; Gracia \& Magistris, 2007; Magistris \& Gracia, 2008). Konsumen yang memiliki pengetahuan tentang pangan organik memiliki sikap positif dibandingkan konsumen lainnya dengan evaluasi bahwa pangan organik bermanfaat bagi konsumen.

Konsumen mengevaluasi produk berupa manfaat yang diperoleh dari pangan organik seperti kesehatan, kealamian, dan keamanan konsumsi. Pengetahuan organik mewakili kemampuan konsumen dalam mengidentifikasi produk organik atau non organik sehingga membentuk sikap positif pada produk organik (Magistris \& Gracia, 2007). Studi meta-analisis menunjukkan ada hubungan pengetahuan dari konsumen dengan sikap pada pangan organik sebesar 0,30 (Chan, 2001). Hipotesis yang diajukan dalam penelitian ini yaitu:

H2: Pengetahuan organik berpengaruh positif terhadap sikap membeli pangan organik

\section{Sikap Membeli pangan Organik}

Hasil penelitian perilaku konsumen menegaskan adanya pengaruh positif dari sikap konsumen terhadap niat beli pangan organik (Chan, 1999; Chan \& Lau, 2000; Wijaya, 2011; Gracia \& Magistris, 2007; Kalafatis et al., 1999; Chiou, 1998; Aertsens et al., 2009; Tarkiainen \& Sundqvist, 2005; Sampson, 2009).

Beberapa konsep seperti teori tindakan beralasan dan perilaku terencana menjelaskan bahwa sikap merupakan prediktor yang akurat bagi perilaku melalui variabel niat (intention). Terbentuknya niat berperilaku dapat diterangkan dengan teori perilaku terencana yang mengasumsikan manusia selalu mempunyai tujuan dalam berperilaku (Fishbein \& Ajzen, 1975). Sikap merupakan komponen utama bagi pembentukan niat. Sikap terbentuk dari dua komponen utama yaitu keyakinan dan evaluasi. Semakin positif keyakinan dari individu, maka akan semakin positif juga sikap individu tersebut, demikian juga sebaliknya (Fisbein \& Ajzen, 1975). Evaluasi atau penilaian individu dapat bersifat positif atau negatif saat menampilkan atau tidak menampilkan perilaku tertentu. Semakin positif sikap terhadap pangan organik maka semakin tinggi niat beli pangan organik.

Hasil penelitian menunjukkan adanya hubungan positif antara sikap membeli pangan organik dan niat beli pangan organik (Chan \& Lau, 2000; Wijaya \& Hidayat, 2011; Gracia \& Magistris, 2007; Kalafatis et al., 1999; Aertsens et al., 2009; Suprapto \& Wijaya, 2012). Studi metaanalisis menunjukkan adanya hubungan sikap membeli pangan organik dengan niat beli sebesar 0,497 . Hipotesis yang diajukan daam penelitian ini yaitu:

H3: Sikap membeli pangan organik berpengaruh positif terhadap niat beli pangan organik

\section{Norma Subjektif}

Norma subjektif faktor lainnya yang memengaruhi niat dalam model yang dikemukakan oleh Fishbein dan Ajzen (1975). Komponen utama dalam norma subjektif adalah kemauan individu mematuhi stimulan dari kelompok referensi. Semakin tinggi motivasi dari individu untuk mematuhi kelompok referensi dalam membeli pangan organik maka semakin tinggi juga niat untuk membeli pangan organik. Faktor-faktor sosial berupa faktor-faktor di sekitar individu berperan sebagai fungsi sosial bagi konsumen seperti kelompok acuan, keluarga, serta peran dan status (Engel et al, 2005). Model acuan memiliki peranan bagi konsumen untuk menentukan pilihan produk dan merek. Keluarga sebagai bagian dari organisasi pembelian konsumen yang paling dekat dengan konsumen sehingga merupakan kelompok acuan primer yang paling berpengaruh dalam pembelian terutama di Indonesia. Faktor referensi menjadi bagian konsumen untuk melakukan pembelian. 
Hasil penelitian tentang konsumen hijau menunjukkan adanya hubungan positif antara norma subjektif dan niat beli pangan organik (Kalafatis et al., 1999; Chiou, 1998; Sampson, 2009; Aertsens et al., 2009; Wijaya \& Hidayat, 2011; Wijaya \& Suprapto, 2012a). Hasil meta-analisis menunjukkan adanya hubungan norma subjektif dengan niat beli sebesar 0,325 . Hipotesis yang diajukan daam penelitian ini yaitu:

H4: Norma subjektif berpengaruh positif terhadap niat beli pangan organik

\section{Kontrol Perilaku}

Faktor lainnya dalam teori perilaku terencana adalah kontrol perilaku yang dirasakan. Faktor ini menggambarkan kondisi dimana individu percaya bahwa suatu perilaku mudah atau sulit untuk dilakukan. Pertimbangan individu mencakup pengalaman masa lalu disamping rintangan-rintangan yang ada, yang dipertimbangkan oleh individu tersebut. Kontrol keperilakuan dipengaruhi oleh kendala realistis yang dipersepsikan oleh individu. Derajat atau kadar kemampuan kontrol perilaku tergantung pada keyakinan individu mengenai ketersediaan sumber daya atau kesempatan dari lingkungan untuk berperilaku. Semakin banyak sumber daya dan kesempatan yang diyakini mampu dikendalikan oleh individu maka semakin tinggi niat untuk berperilaku (Ajzen, 1991).

Hasil penelitian menegaskan ada hubungan positif antara kontrol perilaku dan niat beli pangan organik (Kalafatis et al., 1999; Aertsens et al., 2009; Wijaya \& Hidayat, 2011; Wijaya \& Suprapto, 2012a). Terkait dengan perilaku membeli pangan organik, konsumen mempertimbangkan faktor-faktor yang dianggap mempermudah atau mempersulit membeli pangan organik seperti ketersediaan di pasar, harga pangan, aspek keuangan konsumen, dan adanya informasi keaslian (keabsahan) produk. Hasil meta-analisis menunjukkan adanya hubungan kontrol perilaku dengan niat beli sebesar 0,512. Semakin tinggi keyakinan individu untuk mengendalikan faktor-faktor kontrol perilaku maka semakin tinggi niat beli.

Kontrol keperilakuan memiliki peran langsung terhadap perilaku (Ajzen, 2005; 2008). Perilaku ditentukan oleh keyakinan individu mengenai ketersediaan sumber daya dan kesempatan yang berkaitan dengan perilaku tertentu. Apabila individu memiliki kontrol perilaku yang dirasakan tinggi maka individu akan memiliki kecenderungan untuk melakukan tindakan yang perlu dilakukan. Beberapa hasil penelitian menunjukkan adanya hubungan langsung antara kontrol perilaku seperti harga (Junaedi, 2006), pendapatan (Taner \& Kast, 2003) dengan perilaku membeli pangan organik. Perilaku membeli pangan organik ditentukan faktor-faktor yang secara langsung memudahkan atau mempersulit konsumen membeli pangan organik. Hipotesis yang diajukan dalam penelitian ini yaitu:

H5: Kontrol perilaku berpengaruh positif terhadap niat beli pangan organik

H6: Kontrol perilaku berpengaruh positif terhadap perilaku beli pangan organik

\section{Niat Beli}

Teori perilaku terencana maupun teori tindakan beralasan menjelaskan bahwa perilaku individu dapat diprediksi melalui niat (Azjen, 2008). Hal ini sesuai dengan Ajzen dan Madden (1986) yang menjelaskan bahwa niat berperan terhadap perilaku karena niat dianggap sebagai perantara faktorfaktor motivasional yang memiliki dampak pada suatu perilaku, niat menunjukkan seberapa keras seseorang berani mencoba (upaya), niat juga menunjukkan seberapa banyak upaya yang direncanakan seseorang untuk dilakukan, dan niat merupakan gejala utama yang berhubungan dengan perilaku selanjutnya.

Beberapa temuan penelitian mendukung proposisi hubungan niat beli dengan perilaku membeli pangan organik (Chan, 2001; Chan \& Lau, 2000; Bui, 2005, Follows \& Jobber, 2000; Magnusson et al, 2001). Niat berperan sebagai perantara bagi pengaruh berbagai faktor yang berdampak pada perilaku. Niat memainkan peranan yang khas dalam mengarahkan tindakan, yakni menghubungkan antara pertimbangan yang mendalam yang diyakini dan diinginkan oleh seseorang 
dengan tindakan tertentu. Hasil meta-analisis menunjukkan adanya hubungan antara niat beli pangan organik dengan perilaku membeli pangan organik sebesar 0,49 (Hines et al, 1987). Hipotesis yang diajukan daam penelitian ini yaitu:

H7: Niat beli berpengaruh positif terhadap perilaku beli pangan organik

Berdasarkan kajian teoritik, penelitian terdahulu serta penelitian pendahuluan diajukan model empirik perilaku beli pangan organik. Model teoritik yang diajukan diharapkan sesuai dengan data empirik yang ada di lapangan. Adapun model penelitian perilaku beli pangan organik yang dirangkum dalam penelitian ini sebagai berikut:

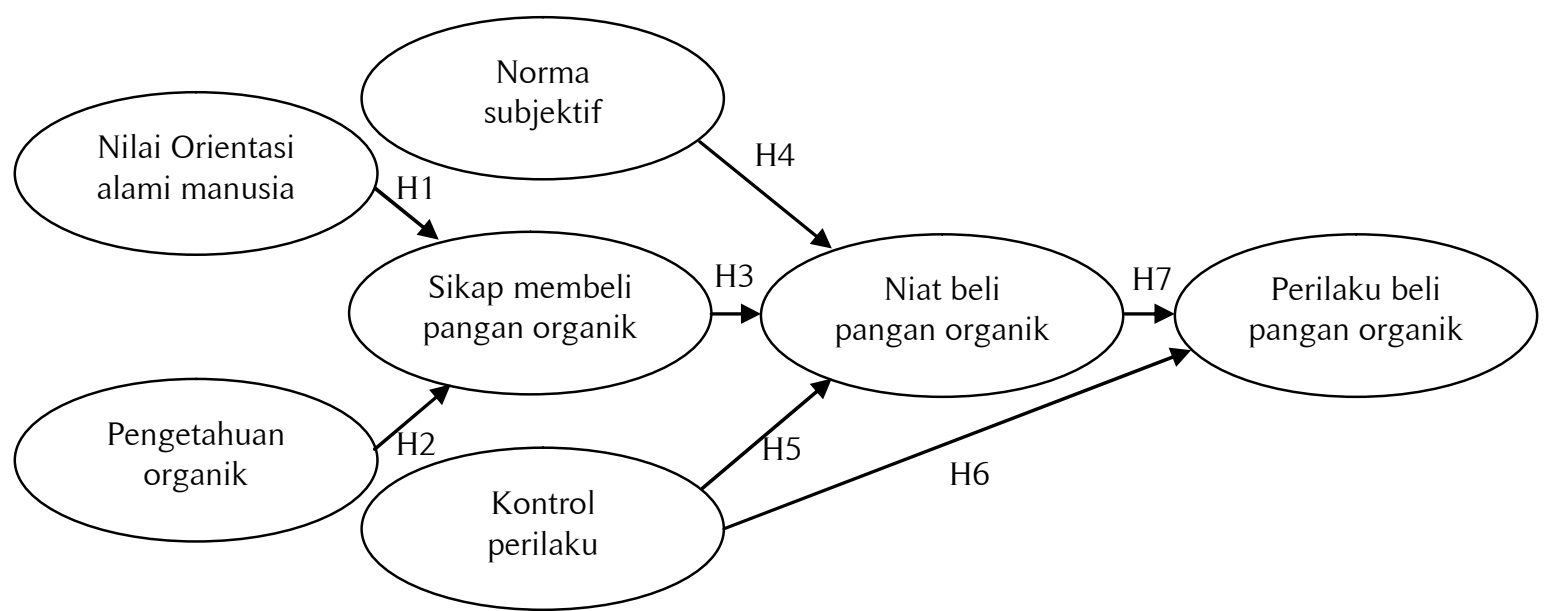

Gambar 2. Model Perilaku Beli Pangan Organik

\section{Metode Penelitian}

Paradigma dalam penelitian ini berorientasi pada paradigma positivisme dengan pengujian hipotesis. Penelitian yang dilakukan bersifat survei. Penelitian ini menggunakan data primer. Metode pengumpulan data dilakukan dengan survei menggunakan kuesioner.

Populasi dalam penelitian ini adalah konsumen pangan organik yaitu konsumen yang melakukan pembelian pangan organik dengan tujuan konsumsi sehari-hari. Teknik sampel menggunakan teknik non probabilitas dengan metode purposive sampling, dan dipilih adalah konsumen yang mengetahui pangan organik dan melakukan pembelian untuk tujuan konsumsi keluarga, mengolah pangan organik seperti sayur dan beras organik, serta memasak untuk konsumsi keluarga sehari-hari. Sejumlah konsumen ditemui di beberapa sentral pasar organik. Responden penelitian dalam penelitian ini berasal dari beberapa kota besar di pulau Jawa yang berjumlah 516 responden.

Tataran data variabel penelitian yang dikumpulkan berbentuk skor data rentang (interval) dan definisi operasional yang berkaitan dengan arti dari seluruh variabel laten yang digunakan dalam penelitian lapangan ini dijabarkan serta dijelaskan sebagai berikut ini:

\section{Variabel perilaku beli pangan organik (PB)}

Perilaku beli pangan organik yaitu perilaku konsumen membeli secara aktual pangan organik untuk dikonsumsi keluarga berdasarkan frekuensi dan jumlah pembelian pangan organik dalam sebulan terakhir. Perilaku beli pangan organik diukur dengan indikator a) membeli pangan organik untuk keluarga secara rutin setiap hari, b) membelanjakan sejumlah uang untuk membeli pangan organik dan c) jumlah pangan organik yang dibeli untuk konsumsi keluarga.

\section{Variabel niat beli pangan organik (IB)}

Niat beli pangan organik yaitu keinginan atau ekspresi niat individu untuk berkomitmen pada aktivitas-aktivitas mengkonsumsi pangan organik (Chan \& Lau, 2000) dilihat dari segi waktu dan 
pilihan. niat beli pangan organik diukur dengan indikator a) mempertimbangkan membeli pangan yang berlabel organik untuk konsumsi keluarga, b) berniat membeli pangan yang diproduksi secara alami di masa mendatang, dan c) mengutamakan pilihan pada pangan organik dalam konsumsi keluarga.

\section{Variabel sikap membeli pangan organik (SB)}

Sikap membeli pangan organik yaitu perasaan atau evaluasi umum tentang membeli pangan organik berdasarkan keyakinan membeli pangan organik dari segi manfaat dan kerugian. Sikap membeli pangan organik diukur dengan indikator a) yakin bahwa pangan organik bermanfaat bagi kesehatan, b) pangan organik aman dikonsumsi keluarga, c) pangan organik tidak tahan lama (cepat rusak) dan d) alami untuk dikonsumsi keluarga (Wijaya \& Hidayat, 2011; Wijaya \& Suprapto, 2012).

\section{Variabel norma subjektif (NS)}

Norma subjektif yaitu keyakinan individu akan normatif, orang sekitarnya dan motivasi individu untuk mengikuti normatif (model) membeli pangan organik. Norma subjektif diukur dengan indikator a) keyakinan mengikuti anjuran anggota keluarga untuk membeli pangan organik bagi konsumsi keluarga, b) merasa yakin mengikuti anjuran teman atau rekan untuk membeli pangan organik bagi konsumsi keluarga, c) merasa yakin mengikuti anjuran media informasi (seperti majalah, televisi dan lain-lain) untuk membeli pangan organik bagi konsumsi keluarga, dan d) merasa yakin mengikuti anjuran pasangan untuk membeli pangan organik bagi konsumsi keluarga (Wijaya, 2009a; Wijaya \& Hidayat, 2011; Wijaya \& Suprapto, 2012).

\section{Variabel kontrol perilaku (KP)}

Kontrol perilaku yaitu persepi terhadap kekuatan faktor-faktor yang mempermudah atau mempersulit perilaku membeli pangan organik berdasarkan keyakinan kekuatan kontrol perilaku untuk pendukung dan penghambat perilaku. Kontrol perilaku diukur dengan indikator a) kemudahan dalam mendapatkan pangan organik (ketersediaan pangan organik di pasar atau toko), b) harga pangan organik terjangkau, c) penghasilan yang cukup untuk membeli pangan organik dan d) ketersediaan informasi keaslian (keabsahan) produk (Wijaya, 2009a; Wijaya \& Hidayat, 2011; Wijaya \& Suprapto, 2012). Data variabel kontrol perilaku diperoleh dari hasil komputasi skor jawaban aitem kuesioner yang diisi oleh responden di pernyataan alat ukur penelitian. Berdasarkan hasil uji coba kuesioner dengan 128 responden diperoleh reliabilitas dengan Cronbach Alpha sebesar 0,934 dengan nilai korelasi butir berkisar 0,804-0,898.

\section{Variabel nilai orientasi alami manusia (OAM)}

Nilai orientasi alami manusia didefinisikan sebagai tendensi hubungan manusia dengan lingkungan yang pada dasarnya akan mengarah pada kehidupan yang harmonis dalam kealamiannya (Chan \& Lau, 2000) yang diukur dengan alat ukur yang dikembangkan dari survey pendahuluan dan disesuaikan kuesioner yang dikembangkan oleh Chan dan Lau, (2000) dan Sihombing (2007). Nilai orientasi alami manusia diukur dengan indikator a) perlunya manusia memahami alam, b) perlakuan terhadap alam sepantasnya, c) menjaga keharmonisan dengan alam, dan d) manusia bagian dari alam. Kuesioner yang digunakan mengacu pada alat ukur yang dikembangkan oleh Chan dan Lau (2000) yang disesuaikan dengan kondisi di lapangan.

\section{Variabel pengetahuan organik (PO)}

Pengetahuan organik didefinisikan sebagai kemampuan konsumen dalam mengidentifikasi sejumlah konsep yang berkaitan dengan produk organik melalui informasi yang dimiliki konsumen (Magistris \& Gracia, 2008; Chan \& Lau, 2000) dilihat dari aspek subjektif dan objektif. Pengetahuan organik diukur dengan indikator a) self report pengetahuan pangan organik, b) memiliki informasi yang cukup tentang pangan organik, c) memahami tanda atau ciri pangan organik, dan d) memahami 
pengertian organik. Alat ukur yang digunakan mengacu pada alat ukur yang dikembangkan oleh Magistris dan Gracia, (2008).

Metode analisis data dalam penelitian menggunakan analisis model persamaan struktural atau disebut Structural Equation Modeling (SEM) dibantu dengan program AMOS.

\section{Hasil Penelitian Dan Pembahasan}

\section{Karakteristik Responden}

Berdasarkan tingkat pendidikan responden, dapat diidentifikasi bahwa mayoritas responden memiliki pendidikan tinggi. Responden yang telah menempuh pendidikan SMU/setingkat sebesar 8\%, responden yang yang telah menempuh pendidikan Diploma (D1-D3) sebesar 14,0\%, responden yang yang telah menempuh pendidikan S1 sebesar $48 \%$, responden yang yang telah menempuh pendidikan S2 sebesar 30\%. Tabulasi karakteristik responden berdasarkan pendidikan disajikan pada Tabel 1.

Berdasarkan data pekerjaan dapat diidentifikasi bahwa mayoritas responden memiliki pekerjaan wiraswasta yaitu sebesar $44 \%$. Responden yang memiliki pekerjaan pegawai negeri sipil sebesar $22 \%$, responden yang memiliki pekerjaan pegawai swasta sebesar $20 \%$, responden yang memiliki pekerjaan ibu rumah tangga sebesar $14 \%$. Tabulasi karakteristik responden berdasarkan pekerjaan disajikan pada Tabel 2.

Berdasarkan tingkat pendapatan keluarga, mayoritas responden tergolong menengah ke atas dengan pendapatan keluarga di atas Rp.9.000.000 yaitu sebesar 66\%. Responden yang memiliki pendapatan Rp. 1.000.000-3.000.000 sebesar 2\%, responden yang memiliki pendapatan Rp. 3.000.100-5.000.000 sebesar 4\%. Responden yang memiliki pendapatan Rp. 5.000.100-7.000.000 sebesar $16 \%$. Responden yang memiliki pendapatan Rp. $7.000 .100-9.000 .000$ sebesar 12\%. Tabulasi karakteristik responden berdasarkan tingkat pendapatan keluarga disajikan pada Tabel 3.

Tabel 1. Pendidikan Responden

\begin{tabular}{lc}
\hline \multicolumn{1}{c}{ Pendidikan } & Jumlah (Persentase) \\
\hline SMU/Setingkat & $52(10,1 \%)$ \\
D1-D3 & $57(11,0 \%)$ \\
S1 & $241(46,7 \%)$ \\
S2 & $163(31,6 \%)$ \\
S3 & $3(0,6)$ \\
\hline Total & $516(100 \%)$ \\
\hline
\end{tabular}

Tabel 2. Pekerjaan Responden

\begin{tabular}{lc}
\hline \multicolumn{1}{c}{ Pekerjaan } & Jumlah (Persentase) \\
\hline Pegawai Negeri Sipil & $85(16,5 \%)$ \\
Pegawai Swasta & $126(24,4 \%)$ \\
Wiraswasta & $211(40,9 \%)$ \\
lbu Rumah Tangga & $94(18,2 \%)$ \\
\hline Total & $516(100 \%)$ \\
\hline
\end{tabular}

Tabel 3. Pendapatan Keluarga

\begin{tabular}{|c|c|}
\hline Pendapatan Keluarga (Rp/bulan): & Jumlah (Persentase) \\
\hline$<1.000 .000$ & \\
\hline $1.000 .000-3.000 .000$ & $4(0,8 \%)$ \\
\hline $3.000 .100-5.000 .000$ & $13(2,5 \%)$ \\
\hline $5.000 .100-7.000 .000$ & $74(14,3 \%)$ \\
\hline $7.000 .100-9.000 .000$ & $111(21,5 \%)$ \\
\hline$>9.000 .000$ & $314(60,9 \%)$ \\
\hline Total & $516(100 \%)$ \\
\hline
\end{tabular}




\section{Pengujian Instrumen}

\section{Uji validitas}

Secara menyeluruh nilai muatan faktor (factor loading) dari masing-masing variabel terobservasi valid dan memenuhi kriteria model pengukuran yang fit secara metodologi. Nilai muatan faktor yang diukur dari variabel laten melalui masing-masing variabel terobservasi berkisar dari 0,64-0,95 di atas 0,5 .

\section{Uji reliabilitas}

Reliabilitas diperlukan untuk ukuran internal konsistensi indikator suatu konstruk dengan mengukur reliabilitas komposit (composite reliability) dan ekstraksi varian (variance extracted). Diketahui nilai koefisien reliabilitas komposit untuk masing-masing variabel berkisar dari 0,74 (sikap membeli pangan organik) hingga 0,92 (pengetahuan organik). Semua variabel berada di atas nilai penerimaan batas reliabilitas yaitu nilai minimum 0,7 .

\section{Analisis Model Persamaan Struktural dan Uji Hipotesis}

Analisis data dalam penelitian ini menggunakan analisis model persamaan struktural (structural equation modelling). Analisis data diawali dengan uji model, yang dilanjutkan dengan pengujian hipotesis. Hasil analisis data diuraikan sebagai berikut.

Uji kesesuaian model persamaan struktural

Hasil uji kesesuaian model menggunakan chi-square, CMIN/DF, GFI, AGFI, RMSEA, TLI, CFI dan ECVI diringkas sebagai berikut:

Tabel 4. Hasil Goodness of Fit Model Pengukuran

\begin{tabular}{lccc}
\hline \multicolumn{1}{c}{ Indeks } & Cut off Value & Hasil & Evaluasi Model \\
\hline Chi square & Mendekati & 315,832 & Baik \\
Probability & $\geq 0,05$ & 0,162 & Baik \\
CMIN/DF & $\leq 2,00$ & 1,082 & Baik \\
GFI & $\geq 0,90$ & 0,957 & Baik \\
AGFI & $\geq 0,90$ & 0,948 & Baik \\
RMSEA & $\leq 0,08$ & 0,013 & Baik \\
TLI & $\geq 0,90$ & 0,997 & Baik \\
CFI & $\geq 0,90$ & 0,998 & Baik \\
ECVI & Default model $<$ saturated model & $0,842<1,363$ & Baik \\
\hline
\end{tabular}

Sumber: Data diolah

Tabel di atas menunjukkan bahwa model penelitian secara keseluruhan fit. Secara keseluruhan nilai Chi square dengan probabilitas sebesar 0,162 > 0,05 menunjukkan keseluruhan model fit (Overall goodness-of-fit).

\section{Uji Hipotesis}

Hasil uji kausalitas model dalam penelitian ini secara lengkap disajikan pada Gambar 3. Hasil bobot regresi antarvariabel laten yang sering disebut sebagai estimasi loading factors atau lambda value dapat digunakan untuk menganalisis uji kausalitas variabel. Berdasarkan signifikansi nilai CR (Critical Ratio) dengan nilai probabilitas $(\mathrm{p})=0.05$. Hasil bobot regresi uji kausalitas disajikan dalam Tabel 5.

Berdasarkan analisis evaluasi bobot regresi tersebut dapat diuraikan dan dijelaskan bahwa variabel nilai orientasi alami manusia berpengaruh positif dan signifikan terhadap sikap membeli pangan organik ( $p=0,007, \beta=0,188$ ). Dengan demikian hipotesis 1 diterima. Hasil temuan penelitian ini konsisten dengan hasil temuan Dreezens et al.,(2005); Krystallis et al.,(2008); Grunert \& Juhl 
(1995); Loureiro et al., (2001); Magnusson et al., (2001, 2003); Durham \& Andrade (2005); Kuhar \& Juvancic (2005); Midmore et al., (2005); Padel \& Foster (2005); Verhoef (2005); Gracia \& de Magistris (2007); Stobbelaar et al., (2007), Chen (2009); Wijaya (2009); Wijaya \& Hidayat (2011), dan Wijaya \& Suprapto (2012a). Hasil temuan menunjukkan semakin tinggi nilai orientasi alami manusia pada konsumen maka semakin baik sikap membeli pangan organik, sebaliknya semakin rendah nilai orientasi alami manusia pada konsumen maka semakin buruk juga sikap membeli pangan organik.

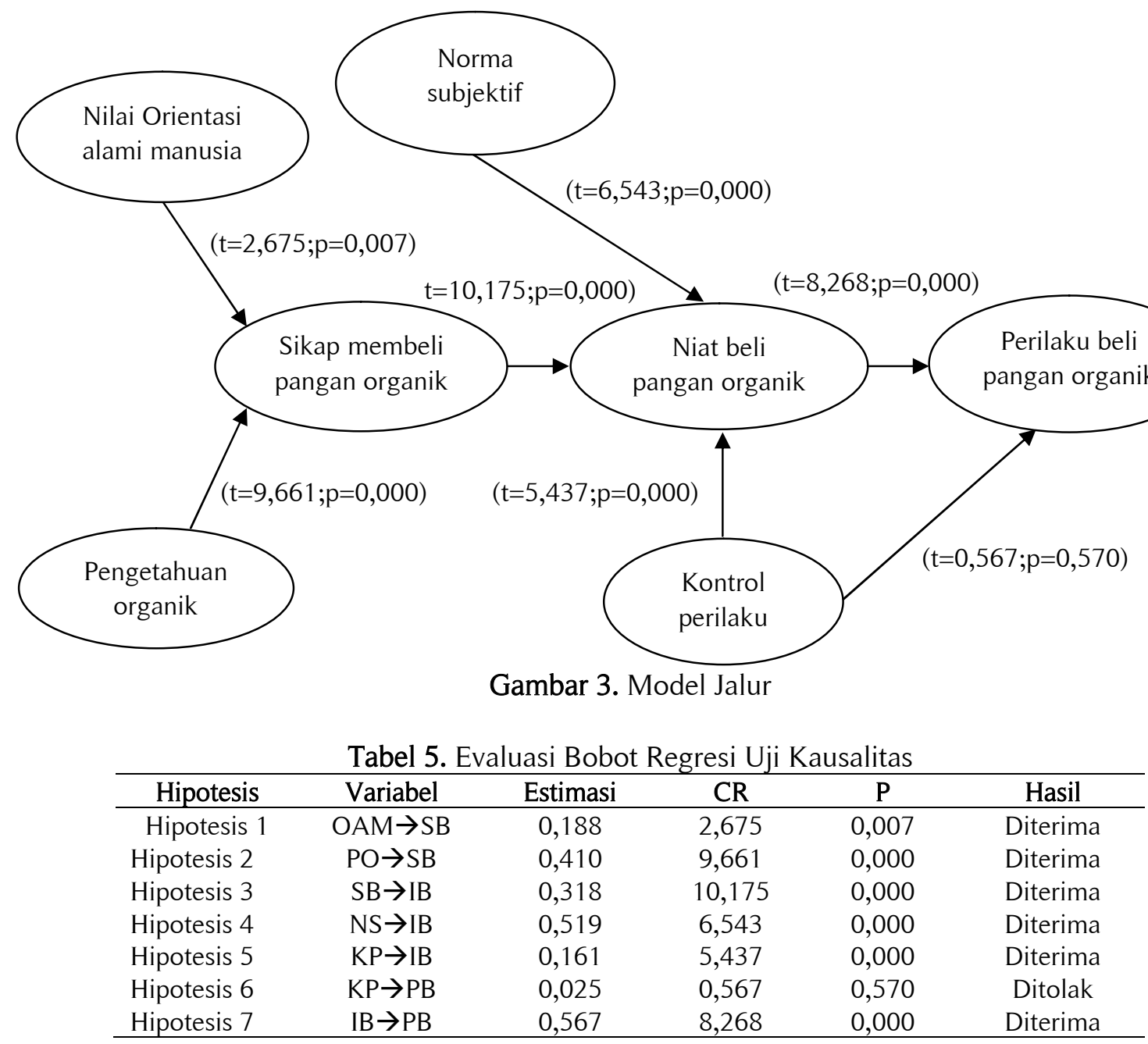

Sumber: Data diolah

Keterangan:

$\begin{array}{ll}\text { OAM } & =\text { Nilai orientasi alami manusia } \\ \text { PO } & =\text { Pengetahuan organik } \\ \text { SB } & =\text { Sikap membeli pangan organik } \\ \text { NS } & =\text { Norma subjektif } \\ \text { KP } & =\text { Kontrol perilaku } \\ \text { IB } & =\text { Niat beli } \\ \text { PB } & =\text { Perilaku beli }\end{array}$

Variabel pengetahuan organik mempengaruhi sikap membeli pangan organik secara positif dan signifikan dengan tingkat signifikansi sebesar 0,000 lebih kecil dari nilai probabilitas $\leq 0,05$. Dengan demikian hipotesis 2 diterima. Hasil temuan ini konsisten dengan temuan Amyx et al., (1994); Vining \& Ebreo, (1990); Chan, (1999); Yiridoe et al., (2005); Poelman et al., (2008); 
Schlegelmilch et al., (1996); Junaedi, (2007); Gracia \& Magistris, (2007); dan Magistris \& Gracia, (2008). Hasil ini menunjukkan semakin tinggi tingkat pengetahuan organik dari konsumen maka semakin baik sikap membeli pangan organik, sebaliknya semakin rendah tingkat pengetahuan organik dari konsumen maka semakin buruk sikap membeli pangan organik.

Sikap merupakan susunan dari keyakinan dan evaluasi terhadap perilaku. Keyakinan dan evaluasi konsumen didasarkan pada berbagai pertimbangan melalui pengetahuan yang dimiliki konsumen. Konsumen yang memiliki pengetahuan organik cenderung memiliki sikap positif terhadap pangan organik karena yakin pangan organik bermanfaat bagi konsumen. Konsumen juga yakin dengan mengkonsumsi pangan organik, konsumen akan memperoleh manfaat seperti kesehatan, kealamian, dan keamanan konsumsi yang dikandung dalam pangan organik. Magistris \& Gracia, (2007) juga menjelaskan bahwa pengetahuan mewakili kemampuan konsumen dalam membedakan produk organik atau non organik serta membentuk sikap positif pada produk organik. Keyakinan terhadap peran hidup sehat merupakan determinan dalam penerimaan pangan (Verbeke, 2004).

Variabel sikap membeli pangan organik mempengaruhi niat beli pangan organik secara positif dan signifikan dengan tingkat signifikansi sebesar 0,000 lebih kecil dari nilai probabilitas $\leq$ 0,05. Dengan demikian hipotesis 3 diterima. Hasil temuan konsisten dengan hasil temuan Chan (1999); Chan \& Lau (2000); Dispoto (1997); Ling-yee (1997); Maloney \& Ward (1973); Wijaya (2009); Wijaya \& Hidayat (2011); Hidayat \& Wijaya (2012); Gracia \& Magistris (2007); Kalafatis et al., (1999); Chiou, (1998); Aertsens et al., (2009); dan Suprapto \& Wijaya (2012). Hasil temuan menjelaskan bahwa semakin kuat sikap membeli pangan organik maka semakin tinggi niat beli, sebaliknya semakin lemah sikap membeli pangan organik maka semakin rendah juga niat beli konsumen.

Variabel norma subjektif mempengaruhi niat beli pangan organik secara positif dan signifikan dengan tingkat signifikansi sebesar 0,000 lebih kecil dari nilai probabilitas $\leq 0,05$. Dengan demikian hipotesis 4 diterima. Hasil temuan sesuai dengan hasil temuan Chan (1999); Chan \& Lau (2000); Dispoto (1997); Ling-yee (1997); Maloney \& Ward (1973); Wijaya \& Hidayat (2011); Hidayat \& Wijaya (2012); Gracia \& Magistris (2007); Kalafatis et al., (1999); Chiou, (1998); Aertsens et al., (2009); dan Suprapto \& Wijaya (2012). Hasil temuan menjelaskan bahwa semakin tinggi norma subjektif maka semakin tinggi niat beli, sebaliknya semakin rendah norma subjektif maka semakin rendah juga niat beli konsumen.

Variabel kontrol perilaku mempengaruhi niat beli pangan organik secara positif dan signifikan dengan tingkat signifikansi sebesar 0,000 lebih kecil dari nilai probabilitas $\leq 0,05$. Dengan demikian hipotesis 5 diterima. Hasil temuan konsisten dengan hasil temuan Chan (1999); Chan \& Lau (2000); Dispoto (1997); Ling-yee (1997); Maloney \& Ward (1973); Wijaya \& Hidayat (2011); Hidayat \& Wijaya (2012); Gracia \& Magistris (2007); Kalafatis et al., (1999); Chiou, (1998); Aertsens et al., (2009); dan Suprapto \& Wijaya (2012). Hasil temuan menjelaskan bahwa semakin tinggi kontrol perilaku maka semakin tinggi niat beli, sebaliknya semakin rendah kontrol perilaku maka semakin rendah juga niat beli konsumen.

Variabel kontrol perilaku tidak berpengaruh signifikan terhadap perilaku beli pangan organik dengan tingkat signifikansi sebesar 0,570 lebih besar dari nilai probabilitas 0,05. Dengan demikian hipotesis 6 ditolak. Kontrol perilaku tidak berpengaruh signifikan terhadap perilaku beli pangan organik ( $p=0,570, \beta=0,025)$. Temuan hasil analisis data menolak hipotesis 6 yang diajukan dalam penelitian. Peran kontrol perilaku menjelaskan perilaku melalui niat atau niat untuk membeli sehingga tidak berdampak langsung pada perilaku. Azjen \& Madden (1986) menjelaskan bahwa kontrol perilaku dapat mempengaruhi perilaku namun dengan mempertimbangkan motivasi untuk berperilaku yang ditunjukkan dengan niat. Lebih lanjut Azjen \& Madden (1986) menjelaskan bahwa saat individu ragu akan kontrol diri untuk berperilaku, hal ini menyebabkan kontrol perilaku tidak berdampak langsung pada perilaku yang ditunjukkan dengan garis putus-putus dalam kerangka hubungan kontrol perilaku dengan perilaku (model teori perilaku terencana). Sebaliknya semakin tinggi keyakinan kontrol perilaku individu akan berdampak langsung pada perilaku. 
Variabel niat beli pangan organik mempengaruhi perilaku beli pangan organik secara positif dan signifikan dengan tingkat signifikansi sebesar 0,000 lebih kecil dari nilai probabilitas $\leq 0,05$. Dengan demikian hipotesis 7 diterima. Temuan hasil analisis data mendukung hipotesis 7 yang diajukan dalam penelitian. Hasil temuan konsisten dengan penelitian Chan (2001); Chan \& Lau (2000); Bui (2005); Follows \& Jobber (2000); Maloney \& Ward (1973); Chan \& Yam (1995); Lingyee (1997), dan Magnusson et al, (2001). Hasil menunjukkan semakin tinggi niat beli maka semakin tinggi perilaku beli pangan organik, sebaliknya semakin rendah niat beli maka semakin rendah juga perilaku beli pangan organik.

Berdasarkan nilai koefisien terstandar dapat diketahui bahwa pengetahuan organik dominan mempengaruhi sikap membeli pangan organik dibandingkan nilai orientasi alami manusia. Besarnya kontribusi variabel secara simultan terhadap variabel lainnya diringkas dalam tabel sebagai berikut:

Tabel 6. Koefisien Determinasi

\begin{tabular}{lcc}
\hline \multicolumn{1}{c}{ Variabel yang mempengaruhi } & Variabel yang dipengaruhi & $\begin{array}{c}\text { Sumbangan } \\
\text { efektif }\end{array}$ \\
\hline $\begin{array}{l}\text { Niat beli } \\
\text { Kontrol perilaku }\end{array}$ & Perilaku beli pangan organik & $17,0 \%$ \\
$\begin{array}{l}\text { Sikap terhadap pangan organik } \\
\text { Kontrol perilaku }\end{array}$ & Niat beli pangan organik & $35,8 \%$ \\
Norma subjektif & & $18,9 \%$ \\
$\begin{array}{l}\text { Orientasi alami manusia } \\
\text { Pengetahuan organik }\end{array}$ & Sikap membeli pangan organik & \\
\hline Sumber: Data diolah & &
\end{tabular}

Berdasarkan tabel di atas dapat diketahui bahwa variabel niat beli dan kontrol perilaku memiliki peran atau kontribusi sebesar $17 \%$ terhadap perilaku beli pangan organik. Variabel sikap membeli pangan organik, norma subjektif dan kontrol perilaku memiliki peran sebesar 35,8\% terhadap niat beli pangan organik. Variabel nilai orientasi alami manusia dan pengetahuan organik memiliki peran sebesar 18,9\% dalam menjelaskan sikap membeli pangan organik.

Pangan organik sebagai produk ramah lingkungan merupakan elemen sistem keyakinan individu (Dembkowski \& Lloyd, 1994). Secara spesifik, Arnould et al., (2004) dan Homer dan Kahle (1988) menjelaskan hubungan nilai dengan perilaku konsumen melalui mekanisme secara hirarki. Nilai berperan dalam membentuk sikap konsumen. Nilai merupakan pertimbangan yang fundamental bagi hubungan konsumen dengan lingkungan. Penduduk Asia memandang diri mereka sebagai bagian dari alam dan hidup harmonis dengan alam atau berorientasi pada alam (de Mooij, 2004) yang disebut Chan (2001) sebagai orientasi alami manusia (Man Nature Orientation). Konsumen yang memiliki orientasi alami manusia cenderung mempertimbangkan akibat-akibat konsumsi pada lingkungan sehingga memiliki sikap ramah lingkungan (Chan, 2001) dan mendukung penggunaan produk organik (Wijaya \& Hidayat, 2011).

Filosofi nilai negara Timur berbeda dengan nilai di negara Barat. Sebagai contoh yang berkaitan dengan alam, nilai-nilai inti yang dianut oleh masyarakat Amerika adalah menaklukkan alam (Engel et al., 2000), berbeda dengan Asia yang cenderung mengutamakan kesimbangan alam (Chan, 2001). Amerika memiliki nilai menaklukkan alam, contohnya seperti menghadapi perubahan alam dan hama dengan bahan kimia, selain itu nilai menaklukkan alam juga ditunjukkan dengan iklan-iklan komersial yang ada (Engel et al., 2000).

Secara kontekstual, negara-negara di Asia memiliki orientasi nilai yang kuat berkaitan dengan produk pangan. Keyakinan akan pangan dan nutrisi pangan yang berkaitan dengan kesehatan dan lingkungan merupakan bagian budaya bagi bangsa Cina, Jepang, Korea dan beberapa negara Asia lainnya (Verschuren, 2002; Westrate et al., 2002). Contohnya Cina dengan ajaran Taoisme yang mengajarkan prinsip bahwa asal manusia dari alam dan menyatu dengan alam (Chan \& Lau, 2000; 
Chan, 2001) sehingga terbentuk keseimbangan (yin dan yang). Filosofi ini berkembang dan mempengaruhi masyarakat Cina lebih dari 2000 tahun (Chan \& Lau, 2000). Penanaman filosofi dilakukan oleh pemerintah Cina melalui jenjang formal seperti lembaga pendidikan atau sekolah maupun non-formal melalui keluarga. Nilai tersebut tumbuh, berkembang dan menyatu dalam kehidupan mereka (Chan, 2001). Penanaman filsofi dilakukan sejak usia dini hingga mengakar dalam kehidupan masyarakat Cina, hal ini tidak terlepas dari dukungan pemerintah.

Masyarakat Indonesia yang memiliki kecenderungan kolektivis memiliki makna hidup untuk harmoni atau seimbang dengan alam (Susana, 2009). Sebagai contoh pemetaan yang dilakukan oleh Susana (2009) berdasarkan Koentjoroningrat menjelaskan bahwa masyarakat yang cenderung kolektivis yang ditunjukkan dengan pembangunan agraris, budaya tradisional, nilai-nilai gotong royong, hidup selaras dengan alam yang dicerminkan lewat acara-acara tradisi seperti slametan, tradisi di gunung merapi dan laut selatan, mengutamakan harmoni dibandingkan ambisi pribadi.

Konsumen membeli produk-produk organik karena memiliki pengetahuan mengenai dampak konsumsi produk pada konsumen dan lingkungan (Chan, 2001). Child \& Poryzees (1998) menjelaskan bahwa kurangnya pengetahuan konsumen tentang kandungan dalam pangan fungsional akan menghambat proses keyakinan konsumen. Hal lain yang bersifat internal dalam membentuk sikap individu untuk berperilaku adalah ketersediaan informasi, keterampilan dan kemampuan yang memperkuat motivasi individu. Sikap cenderung berubah sesuai perubahan tingkat pengetahuan (Aertsens et al., 2009). Pengetahuan organik menyediakan informasi mengenai pangan organik dan manfaatnya sehingga memperkuat motivasi individu dalam mempertimbangkan pembelian pangan organik.

Sesuai konsep dasar teori perilaku terencana menunjukkan bahwa sikap merupakan prediktor yang baik bagi niat berperilaku. Teori perilaku terencana menyebutkan bahwa niat adalah fungsi dari determinan sikap terhadap perilaku, yang merupakan dasar bagi pembentukan niat. Menurut Ajzen (1986) terwujud tidaknya niat sangat tergantung pada faktor eksternal dan internal. Faktor internal tergantung pada keyakinan dari individu dalam berperilaku dan dapat tidaknya berperilaku sedangkan faktor eksternal merupakan stimulus yang mendorong individu untuk berperilaku. Konsumen yang memiliki sikap yang positif terhadap pangan organik berdasarkan keyakinan dan evaluasi akan mengkonsumsi pangan organik karena dianggap bermanfaat bagi mereka sehingga menstimulasi niat konsumen membeli pangan organik.

Konsumen dalam memutuskan pembelian pangan organik mempertimbangkan model yang menjadi acuan serta kesediaan untuk mematuhi harapan dari norma referensi untuk mengkonsumsi pangan organik yaitu anjuran anggota keluarga, rekan maupun media yang dijadikan acuan seperti televisi dan majalah. Kelompok referensi tersebut yang menjadi stimulus konsumen dalam merespon pembelian pangan organik. Keluarga adalah organisasi pembelian konsumen yang paling penting dalam masyarakat, dan menjadi obyek penelitian yang ekstensif (Engel et al., 2000). Anggota keluarga merupakan kelompok acuan primer yang paling berpengaruh dalam pembelian karena paling dekat dengan individu terutama di Indonesia yang cenderung kolektif.

Pentingnya peran norma subjektif dalam konteks konsumen Indonesia dibuktikan dalam penelitian ini. Norma subjektif yang masih jarang dipertimbangkan dalam penelitian khususnya di Eropa membawa dampak perbedaan hasil dengan penelitian ini. Hal ini juga didukung oleh budaya di Indonesia yang cenderung lebih kolektif berbeda dengan budaya di masyarakat Barat yang cenderung lebih individualis. Masyarakat Indonesia masih memperhatikan pentingnya norma atau memandang apa yang seharusnya dilakukan atau diharapkan masyarakat. Harapan dari orang banyak atau masyarakat terkristalisasi dalam hal pengambilan keputusan konsumsi pangan organik.

Kontrol perilaku memuat keyakinan individu yang berkaitan perasaan mampu atau tidak mampu dalam mengendalikan perilaku dan keyakinan mengenai ada atau tidaknya faktor-faktor yang memudahkan atau mempersulit individu untuk berperilaku. Untuk menampilkan niat membeli pangan organik, konsumen mempertimbangkan faktor-faktor yang memudahkan atau mempersulit konsumen membeli pangan organik seperti ketersediaan di pasar, harga pangan, aspek keuangan 
konsumen, dan adanya informasi keaslian (keabsahan) produk, berbeda dengan negara-negara lain seperti Eropa yang telah melegalisasi keabsahan produk organik dan tersedia secara luas karena tingkat produksi organik yang tinggi beserta distribusi yang merata

Kontrol perilaku tidak berpengaruh signifikan terhadap perilaku beli pangan organik untuk konteks konsumen Indonesia. Berdasarkan studi eksplorasi sebelumnya, diperoleh informasi bahwa secara menyeluruh konsumen mempersepsikan adanya kesulitan dalam mengendalikan aspek-aspek kontrol perilaku seperti keabsahan atau keaslian pangan organik keuangan konsumen, dan ketersediaan di pasar karena saat ini mayoritas pangan organik hanya tersedia di pasar modern. Beberapa responden merasa ragu bahwa pangan organik yang sekedar diberi label organik adalah asli atau benar-benar organik. Konsumen membutuhkan jaminan atau indikator keabsahan bahwa produk yang dibeli merupakan produk organik. Hal ini yang menjadikan kontrol perilaku konsumen menjadi rendah sehingga tidak berdampak pada perilaku secara langsung.

Niat merupakan prediktor yang kuat bagi perilaku sesuai model dasar teori perilaku terencana. niat berperan terhadap perilaku karena niat dianggap sebagai perantara faktor-faktor motivasional yang mempunyai dampak pada suatu perilaku, niat menunjukkan seberapa keras seseorang berani mencoba (upaya), niat juga menunjukkan seberapa banyak upaya yang direncanakan seseorang untuk dilakukan, dan niat adalah paling dekat berhubungan dengan perilaku selanjutnya. niat anteseden langsung (immediate antecedent) terhadap perilaku (Ajzen, 1986) sehingga memiliki konsistensi yang tinggi dengan perilaku, meskipun tinggi rendahnya niat sangat tergantung dari stimulus faktor internal seperti sikap dan mudah tidaknya berperilaku dan faktor eksternal seperti pengaruh lingkungan.

\section{Simpulan dan Saran}

Berdasarkan pembahasan dapat disimpulkan bahwa terdapat kesesuaian antara model perilaku beli pangan organik dengan data penelitian yang menggambarkan pengaruh orientasi alami manusia, pengetahuan organik, sikap terhadap pangan organik, norma subjektif, kontrol perilaku dan niat beli terhadap perilaku beli pangan organik. Hal ini didukung dengan persyaratan goodness of fit dari model. Dengan demikian model dalam penelitian ini dapat diaplikasikan dalam konteks konsumen pangan organik khususnya perilaku beli pangan organik beserta faktor-faktornya. Model penelitian ini termasuk kategori baru dan belum pernah diteliti oleh peneliti sebelumnya. Penelitian ini membuktikan bahwa perluasan theory planned of behaviour dapat digunakan dalam memprediksi perilaku beli pangan organik.

Nilai orientasi alami manusia memiliki pengaruh positif dan signifikan terhadap sikap membeli pangan organik. Hal ini berarti semakin tinggi nilai orientasi alami manusia, maka semakin baik juga sikap membeli pangan organik. Pengetahuan organik memiliki pengaruh positif dan signifikan terhadap sikap membeli pangan organik. Hal ini berarti semakin tinggi pengetahuan organik, maka semakin baik juga sikap membeli pangan organik. Sikap membeli pangan organik memiliki pengaruh positif dan signifikan terhadap niat beli pangan organik. Hal ini berarti semakin baik sikap membeli pangan organik, maka semakin tinggi niat beli pangan organik. Norma subjektif memiliki pengaruh positif dan signifikan terhadap niat beli pangan organik. Hal ini berarti semakin tinggi norma subjektif, maka semakin tinggi juga niat beli pangan organik. Kontrol perilaku memiliki pengaruh positif dan signifikan terhadap niat beli pangan organik. Hal ini berarti semakin tinggi kontrol perilaku, maka semakin tinggi juga niat beli pangan organik. Kontrol perilaku tidak berpengaruh signifikan terhadap perilaku beli pangan organik. Peningkatan kontrol perilaku tidak bermakna atau tidak menyebabkan perubahan yang berarti bagi perilaku beli pangan organik. Niat beli memiliki pengaruh positif dan signifikan terhadap perilaku beli pangan organik. Hal ini berarti semakin tinggi niat beli, maka semakin tinggi juga perilaku beli pangan organik.

Secara praktis, beberapa pertimbangan kontribusi praktis berupa implikasi manajerial yang bermanfaat bagi pemasar maupun pihak lainnya yaitu: 1) Berkaitan dengan pengaruh aspek pengetahuan terhadap sikap beli pangan organik, produsen organik khususnya yang bergerak di 
bidang pangan organik perlu memberikan informasi dalam proses edukasi konsumen seperti pemberian label organik dan informasi seperti manfaat pangan organik bagi kesehatan. Manfaat yang dapat diperoleh dari setiap jenis pangan organik. Komunikasi perlu dibangun oleh produsen dalam proses transfer informasi produk organik ke konsumen. Kim et al., (2001) berpendapat bahwa label pangan merupakan alat komunikasi yang digunakan untuk memenuhi kebutuhan informasi dan kesehatan. Secara umum informasi yang diberikan meliputi merek, isi, kandungan bahan, mineral, vitamin, logo untuk klaim tertentu misalnya ramah lingkungan, klaim kesehatan, anjuran informasi dan penggunaan pola makan sehat (Hingginson et al., 2002). Label pangan merupakan cara yang bermanfaat untuk membantu konsumen menentukan pilihan produk sesuai dengan tujuan kesehatan (Worsley, 2002). Selain itu label pangan dapat menurunkan ketidakpastian yang dihadapi konsumen (Zarkin \& Anderson, 1992), mempengaruhi persepsi, preferensi, ekspektasi sebelum pembelian dan evaluasi sesudah pembelian (Ford et al., 1990). Argumentasi penggunaan klaim kesehatan merupakan cara yang paling rasional untuk mengkomunikasikan pengetahuan produk yang dapat memberikan efek kesehatan yang bermanfaat bagi konsumen (Oversen, 1999). 2) Berdasarkan peran dari nilai orientasi alami manusia, diperlukan adanya penanaman nilai yang berorientasi alami manusia melalui sosialisasi kesadaran akan perilaku ramah lingkungan. Sosialisasi kesadaran akan ramah lingkungan dapat ditanamkan dari generasi ke generasi melalui jenjang formal seperti sekolah maupun non formal seperti keluarga. Cina contohnya, penanaman filosofi dilakukan oleh pemerintah melalui jenjang formal seperti lembaga pendidikan atau sekolah maupun non-formal melalui keluarga yang dilakukan sejak usia dini hingga mengakar dalam kehidupan masyarakat. Peran pemerintah diperlukan dalam hal ini, sehingga akan tumbuh sikap positif dalam konsumsi produk organik yang berdampak pada pola konsumsi ramah lingkungan. Edukasi yang berbasis ramah lingkungan perlu mendapat perhatian dari pemerintah. Melalui penanaman nilai orientasi alami manusia diharapkan mampu mencegah atau mengurangi degradasi lingkungan di Indonesia. Penanaman nilai juga akan menyadarkan manusia pentingnya hubungan manusia dengan alam sehingga tercipta pola konsumsi sehat berbasis ramah lingkungan. 3) Berkaitan dengan peran aspek norma subjektif, pemasar perlu mendekati kelompok referensi keluarga atau memperhatikan kelompok referensi sebagai bagian dari target komunikasi pemasaran, anggota keluarga merupakan kelompok acuan primer yang paling berpengaruh dalam pembelian pangan organik. Meskipun pembelian dilakukan oleh individu, keputusan pembelian sangat mungkin dipengaruhi oleh anggota lain dalam keluarga (Engel et al., 2005). Masyarakat Indonesia sebagai bagian budaya Asia, cenderung kolektif sehingga keputusan individu sangat dipengaruhi oleh kelompok referensi. Selain itu produsen pangan organik juga dapat menggunakan media televisi dan majalah sebagai media komunikasi pemasaran pangan organik. Hal ini didukung dengan data eksplorasi bahwa media yang dijadikan acuan dalam konsumsi pangan organik adalah televisi dan majalah. 4) Dilihat dari aspek kontrol perilaku, pemerintah atau pihak independen perlu menjamin legalitas keaslian produk atau pangan organik bukan hanya sebatas logo organik dan melakukan pengawasan legalitas keaslian produk. Hal ini berfungsi meyakinkan konsumen atau meminimalisir keraguan konsumen akan keabsahan atau keaslian produk organik. Klaim organik harus memenuhi standar organik dari proses pembibitan hingga panen. Pangan organik dengan bibit organik belum tentu diakui sebagai pangan organik apabila dalam proses penanaman menggunakan pupuk yang tidak organik. Dengan demikian perlu dibentuk lembaga sertifikasi organik yang berperan dalam menjaga keabsahan produk organik misalnya melibatkan perguruan tinggi dalam upaya sertifikasi organik. Sertifikasi merupakan isu terpenting di Asia, hal ini terjadi karena tingginya tuntutan konsumen adanya jaminan kepastian bahwa produk yang akan dibeli adalah organik yang asli. Selain itu sampai saat ini lembaga atau badan sertifikasi organik dari dalam negeri sangat terbatas jumlahnya. Di Indonesia, sampai saat ini lembaga penjamin produk organik dari luar negeri baru ada 2 yakni Nasa (Australia) dan Scall (Belanda). Biaya yang dibutuhkan petani dalam proses sertifikasi juga termasuk tinggi. 


\section{Daftar Pustaka}

Aertsens, J, Verbeke, W., \& Huylenbroeck, G, V. (2009). Personal determinants of organic food consumption: A review. British Food Journal. 10, 1140-1167.

Ajzen, I., \& Madden, T.J. (1986). Prediction of goal directed behavior: Attitudes, intentions and perceived behavior control. Journal of Experimental Social Psychology, 22, 457-474.

Ajzen, I. (1987). Attitudes, traits, and action: Dispositional prediction of behavior in personality and social psychology, Diunduh dari www.people.umass.edu/aizen tanggal 9 Desember 2008.

Ajzen, I. (1991). The theory of planned behavior. Organizational Behavior and Human Decision Process, 50, 179-211.

Alba, J. W., \& Hutchinson, J. W. (1987). Dimension of consumer expertise. Journal of Consumer Research, 13, 411-454.

Amyx, D, A, Dejong, P, F., Lin, X C,G., \& Weiner, J, L. (1994). Influencer of purchase intentions for ecologically safe products; an exploratory study. The proceeding of the 1994 American Marketing Association's Winter Educators Conference. 5, AMA, Chicago,341-344.

Arbuthnot, J \& Lingg, S. (1975). A comparison of French and American environmental behaviours, knowledge and attitudes. International Journal of Psychology, 10 (4), 275-281

Arnould, E.J., Price, L.L., \& Zinkhan, G.M. (2004). Consumers. New York: McGraw-Hill.

Bui, M.H. (2005). Environmental marketing: A model of consumer behavior. Proceedings of the Annual Meeting of the Association of Collegiate Marketing Educators.

Chan, R.Y.K. (1999). Environmental attitudes and behavior of consumers in china: Survey findings and implications. Journal of International Consumer Marketing, 11, 25-52.

Chan, R.Y.K. (2001), Determinants of chinese consumers green purchase behavior. Psychology \& Marketing, 8, 389-413.

Chan, R.Y.K., \& Lau, L.B.Y. (2000), Antecedents of green purchases: A survey in china, Journal of Consumer Marketing, 17.338-357.

Chen, T,B \& Chai, L, T. (2010), Attitude towards the environment and green product: consumer perspective. Management Science and Engineering, 4 (2), 27-39

Chiou, J.S. (1998). The effects of attitude, subjective norm, and perceived behavioral control on consumers' purchase intentions: The moderating effects of product knowledge and attention to social comparison information. Proc. Natl. Sci. Counc. ROC (C) 9, 298-308.

Churchill, G. A. (1979). A paradigm for developing better measures of marketing constructs. Journal of Marketing Research, 16, 67-73.

Dembkowski, D, S., \& Lloyd, S, H. (1994). The environmental value attitude system model. Journal of Marketing Management. 19, 593-603

De Mooij, M. (2004).Consumer behavior and culture: Consequences for global marketing. California: Sage.

Dispoto, R.G. 1997. Interrelationships among measures of environmental acitivity, emotionality and knowledge. Educational and Psychological Measurement, 37, 451-459.

Dreezens, E., Martijn, C., Tenbult, P., Kok, G., \& de Vries, N, K. (2005). Food and values; an examination of values underlying attitudes toward genetically modified and organically grown food products. Appetite, 44 (1), 115-122. 
Durham, C, A., \& Andrade, D. (2005). Health vs environmental motivation in organic preferences and purchases. Paper presnted at the American Agricultural Economics Association Annual Meeting, Providence, 24-27 July.

Engel, J.F., Roger, D.B., \& Paul, W. M. (2005), Consumer behavior. International Edition, Forth Worth : Dreyden Press.

Fishbein, M., \& Ajzen, I. (1975), Belief, attitude, intention and behavior: An introduction to theory and research. Menlo Park, California; Addison-Wesley Publishing Company Inc.

Follows, S. B., \& David. J. (2000), Environmentally responsible purchase behavior: a test of a consumer model. European Journal of Marketing, 34, 723-746.

Fraj, E., \& Martinez, E. (2006). Environmental values and lifestyles as determining factors of ecological consumer behaviour: An emprical analysis. Journal of Consumer Marketing, 23 (3), 113-144.

Gracia, A., \& Magistris, T. (2007). Organic food product purchase behaviour: a pilot study for urban consumers in the South of Italy. Spanish Journal og Agricultural Research, 5 (4), 439-451.

Grunert, S.C., \& Juhl, H, J. (1995). Value, environmental attitudes, and buying of organic foods. Journal of Economic Psychology, 16, 39-62.

Hines, J. M., Hungerford, H. R., \& Tomera, A. N. (1987). Analysis and synthesis of research on responsible environmental behavior: A meta-analysis. Journal of Environmental Education, $18,1-8$.

Hingginson, C, S., Rayner, M, J.,Draper, S., \& Kirk,T,R. (2002).The nutrition label-which information is looked at?. Nurition and Food Science, 32 (3), 92-99.

Homer, P.M., \& Khale, L.R. (1988). A structural equation test of the value-attitude-behavior hierarchy. Journal of personality and Social Psychology, 54, 638-646.

Junaedi, S. (2006). Pengembangan model perilaku konsumen berwawasan lingkungan di Indonesia: Studi perbandingan kota metropolitan dan non metropolitan. Jurnal Ekonomi dan Bisnis Indonesia, 21, 399-419.

Junaedi, S. (2007). The roles of consumer knowledge and emotion toward ecological issue: an empirical study of green study consumer behavior. International Journal of Business, 9,81-99.

Kalafatis, S. P., Michael., Robert, E., \& Markos H. T. (1999). Green marketing and ajzen's theory of planned behavior: A cross-market examination, Journal of Consumer Marketing, 16, 441-460.

Kim, S,Y.,Nayga, R, M., \& Capps, JR. (2001). Food label use, self selectivity, and diet quality. The Journal of Consumer Affair 35 (2), 246-363.

Kluckhohn, F.R., \& Strodtbeck, F.L. (1961). Variations in value orientations. Evanston, Ill.: Row, Peterson.

Krystallis, A., Vassallo, M., Chryssohoidis, G., \& Perrea, T. (2008). Societal and individualistic drivers as predictors of organic purchasing revealed through a portrait value questionnaire (PVQ) based inventory, Journal of Consumer Behaviour, 7, 164-187.

Kuhar, A., \& Juvancic, L. (2005). Modelling consumer preferences toward organic and integrated fruits and vegetables in Slovania, Paper presented at 97th EAAE Seminar on The Economics and Policy of Diet and Health, Reading.

Laroche, M., Jasmin, B., \& Guido, B. F. (2001). Targeting consumers who are willing to pay more for environmentally friendly products, Journal of Consumer Marketing, 18, 503-520. 
Ling-yee, Li. (1997). Effect of collectivist orientation and ecological attitude on actual environmental commitment: The moderating role of consumer demographics and product involvement. Journal of International Consumer Marketing, 9, 31-53.

Lodorfos, G.N., \& Dennis, J. (2008). Consumers' intent: in the organic food market. Journal of Food Products Marketing, 14(2), 17-38.

Loureiro, M, J., McCluskey, J,J., \& Mittelhammer, R. C. (2001). Assesing consumer preferences for organic, eco-labeled and regular apples, Journal of Agricultural and Resource Economics, 26 (2), 404-416.

Magistris, T., \& Gracia, A. (2008). The decision to buy organic food products in Southern Italy. British Food Journal, 10, 929-947.

. (2007). Organic food product purchase behaviour: A pilot study for urban consumers in the South of Italy. Spanish Journal of Agricultural Research, 5(40, 439-451.

Magnusson, M.K., Arvola, A., Hursti, U.K., Aberg, L., \& Sjoden., P. (2001). Attitudes towards organic foods among Swedish consumers. British Food Journal, 103, 209-226.

Maloney, M.P., \& Ward, M.P. (1973). Ecology: Lets hear from the people: An objective scale for the measurement of ecological attitudes and knowledge. American Psychologist, 28(7), 583-586

Mansaray, A. and Abijoye, J.O. (1998). Environmental knowledge, attitudes and behavior in Dutch secondary school, Journal of Environmental Education, 30(2), 4-11.

Midmore, P., Naspetti, S., Sherwood, A, M., Vairo, D., Wier, M., \& Zanoli, R. (2005). Consumer attitudes to quality dan safety of organic and low input foods: A review. University of Wales, Aberystwyth.

Nord, M. (2009). Food insecurity in households with children: Prevalence, severity and household characteristics. Economic Information Bulletin, (56)

Padel, S., \& Foster, C. (2005). Exploring the gap between attitudes and behaviour: Understanding why consumers buy or do not buy organic food. British Food Journal, 107 (8), 606 - 625.

Peattie, S. (1998). Promotional competition as a marketing tool on food retailing. British Food Journal, 100, 286 - 294.

Poelman, A.,Mojet, J.,Lyon, D \& Sefa-Dedeh, S. (2008). The influence of information about organic production and fair trade on preference for and perception of pineapple. Food Quality and Preference, 19 (1), $114-121$.

Sampson, L.K. (2009). Consumer analysis of purchasing behavior for green apparel. Thesis. North Carolina State University.

Santrock, J.W. (2005). Psychology. McGraw-Hill Book Company, Inc: New York.

Schlegelmilch, B,B.,Bohlen, G, M., \& Diamantopoulos, A. (1996). The link between green purchasing decisions and measures of environmental consciousness. European Journal of Marketing, 30 (5), 35 - 55.

Sihombing, S.O. (2007). Predicting environmentally purchase behavior: A test of the value-attitudebehavior hierarchy. The 2nd Indonesian Business Management Conference, Jakarta, 30 Januari.

Stobbelaar, D, J., Casimir, G., Borghuis, J., Marks, I, Meijer, L., \& Zebeda, S. (2007). Adolescents attitudes toward organic food: a survey of 15 to 16 year old school children. International Journal of Consumer Studies, 31, 349-356. 
Susana, T. (2009). Pengaruh orientasi budaya individual, jenis kelamin, dan orientasi budaya masyarakat terhadap gejala somatisasi dan depresi murni. Disertasi doktor tidak diterbitkan, Fakultas psikologi UGM.Yogyakarta: Universitas Gadjah Mada.

Syahlani, S, P. (2006). Efek informasi, sumber komunikasi pemasaran dan label pangan dalam proses adopsi: Studi perilaku adopsi pangan fungsional. Disertasi doktor tidak diterbitkan, Fakultas Ekonomi UGM.Yogyakarta: Universitas Gadjah Mada.

Taner, C., \& Kast, S.W. (1999). Promoting sustainable consumption: Determinants of green purchases by Swiss consumers. Psychology \& Marketing. 20 (10), 883-902.

Tarkiainen, A., \& Sundqvist, S. (2005). Subjective norms, attitudes and intentions of Finnish consumers in buying organic food. British Food Journal, 107 (11), 808-822.

Umberson, K, B, S. (2008). Environmentally friendly purchase intention: Debunking the misconception behind apathetic consumer attitudes. Thesis, University of North Texas: Texas.

Verbeke, W. (2000). Influence on the consumer decision making process towards fresh meat: Insight from Belgium and implications. British Food Journal, 102 (7), 522-538.

Verhoef, P, C. (2005). Explaining purchase of organic meat by Dutch consumer. European Review of Agricultural Economics, 32, 245-267.

Verschuren, P.M., (2002). Functional foods: Scientific and global perspectives. British Journal of Nutrition, 88, S125-S130

Vining, J., \& Ebreo, A. (1990). What makes a recycler? A comparison of recycler and nonrecycler. Environmental Behavior, 22, 55-57.

Vlosky, R. P., Lucie, K. O., \& Renee J. F. (1999). A conceptual model of US consumer willingness-to-pay for environmentally certified wood products. Journal of Consumer Marketing, 16, 122-136.

Westrate , J. A., Poppel, G. van \& Verschuren, P, M. (2002). Functional foods, trends and future. British Journal of Nutrition, 88, S233-S235.

Wijaya, T., \& Hidayat, A. (2011). Model niat pembelian pangan organik. Call for Paper Update Ekonomi, Akuntansi dan Bisnis Indonesia, Proceeding Fakultas Ekonomi UII-Yogyakarta, 28 Juni.

Wijaya, T., \& Suprapto, B. (2012)a. Model of buying intention on organic food. International Conference in Marketing, Proceeding Lucknow-India, 12-14 January.

Wijaya, T., \& Suprapto, B. (2012)b. Intention of indonesian consumers on buying organic food. International Journal of Trade, Economics and Finance, 3 (2), 114-119.

Worsley, A., \& Scott, Victoria. (1999). Consumer's concern about food and health in Australia and New Zealand. Asian Pacific Journal. 9, 24-32.

Worsley, A. (2002). Nutrition communication: do we need a new outlook?. Asian Pacific Journal Clinical Nutrition. 11, 708-718.

Yiridoe, E, K., Bonti-Ankomah, S., \& Martin, R, C. (2005). Conparison of consumers perception towards organic versus conventionally produced foods; a review and update of the literature. Renewable Agriculture and Food System, 20 (4), 193-205.

YLKI. (2012). Survei Konsumen Organik Indonesia. Diunduh melalui http://www.organicindonesia.org/05infodata-news.php?id=443. 